\title{
THE MERGING OF NATIONAL AND STATE POLITICS.
}

By John Haynes,

of Johns Hopkins UnIVERsity.

An American is subject to two sovereign powers. If he be a voter he is a partner in two governments. No principle is more firmly intrenched in the literature of constitutional law than the doctrine that the spheres of the National and State Governments are distinct, and each within its sphere supreme. "The dividing line between sovereignties is usually a territorial line," says Judge Cooley; "in American constitutional law, however, there is a division between the National and State Governments by subjects, the former being possessed of supreme, absolute and uncontrovertible power over certain subjects throughout all the States and Territories, while the States have the like complete power within their respective territorial limits over other subjects." "The powers of the General Government and of the State, though both exist and are exercised within the same territorial limits," says the United States Supreme Court, " are yet separate and distinct sovereignties, and the sphere of action appropriated to the United States is as far beyond the reach of the judicial processes issued by a State judge or a State court as if the line of division was traced by landmarks visible to the eye."

This feature of our government is the pride of American writers and the admiration of foreign critics.

Following this principle to its logical conclusion we might expect to find the same sharp division in the politics of the land; inferring that National politics would centre about the great questions whose decision must be reached in the National Capitol and that State politics would deal with questions falling within the jurisdiction of each State.

We might suppose that there would be two sets of parties, the people of the country at large being divided into two or more political camps along the lines suggested by issues of National concern, while the people of each State were divided into such parties as local circumstances might call into existence. Such a condition of politics would manifestly be in a high degree favorable to good government. But the facts are the exact reverse of 
this ideal conception. State parties do not exist and never have existed except in a few instances and for short periols of time. In State elections the vote is divided between the same parties as in National elections, for the most part in the same proportion, and with unfavorable results, as this paper aims to show, both to State and Nation, though chiefly to the former.

The reasons for this are not far to seek. Men who are associated in one line of effort, be it social, religious or political, naturally tend to associate in other activities. Those who work together for the accomplishment of a desired end in National politics, by reason of their acquaintance with one another and with the voters of the locality in which they live, come to coöperate in local politics. The same tendency causes men associated for the advancement of purely local projects to work together in a wider field. The result is two strong political organizations pitted against each other in every election. While it is perhaps inevitable and, it may be, desirable that our present party system should be retained in its general features, its disadvantages are capable of much amelioration through the action of independent voters. One of the most favorable signs of the times is the increasing tendency among such voters to discriminate sharply between State and National issues. The recent action of Massachusetts in re-electing a democratic governor while at the same time she pronounced unequivocally against the policy of his party in national affairs is the most striking instance of this trend, though evidence of it is not lacking in other quarters.

But there is a force preventing the just separation of the spheres of our political activity stronger than the tendency to which allusion has been made, and for which independent voting is a powerless remedy. This force is constitutional and statute law.

The United States Constitution and National Statutes are not completely consistent with the great fundamental principle that the spheres of action of the State and National Governments are separate and distinct.

The constitutional provision that United States Senators shall be elected by the Legislatures of the respective States and the statutory provision that the several Legislatures shall divide the States into congressional districts, give to the legislative department of the States, including of course the Governor, a power which has a direct and vital relation to National politics.

The reasons which led the framers of our Constitution to prescribe this method of electing United States Senators are not given at length in the histories of their deliberations, but they thought, 
no doubt, that an indirect method was most likely to result in the choice of able and efficient Senators, just as they thought an indirect method best for the election of the President. In nothing did the Convention so conspicuously fail to forsee the effect of its action as in the matter of the election of President, which now has all the disadvantages of a popular election and none of the supposed advantages of an indirect choice.

Under our party system the actual method of electing Senators has departed almost as far from its original design as the method of choosing the President. "It is worth observing," says James Bryce, "that the election of Senators has in substance almost ceased to be indirect They are still nominally chosen, as under the letter of the Constitution they must be chosen, by the State Legislatures." * * * "It is now generally true that in most States little freedom of choice remains with the Legislature. The people, or rather those wire-pullers who manage the people, and act in their name, have practically settled the matter at the election of the State Legislature. So hard is it to make any scheme of indirect election work according to its original design."

While this statement of the matter may be somewhat too strong, there is abundant reason to believe that were the Senators elected by the people of the several States, most of the able and useful men who now hold seats in that body would still be found there. Most exceptions to the rule would be members who owe their election to Legislatures not of the same political party as the majority of the voters in their States.

But, granting that the indirect method has some advantages, they cannot be substantial enough to compensate for the disadvantages incident to the intrusion of National affairs into State politics.

This intrusion hampers the voter in the expression of his will. In casting his ballot he must often choose whether he will express his convictions on National or State questions. If he expresses them fully on National questions he is often not only precluded from a full expression on State questions, but is compelled to indorse State policies with which he has anything but sympathy. Are there instances of this in actual experience ? Their name is legion. Let us take a single one. The elections of $x 890$ and $I 892$ show that there is in Iowa a body of voters large enough to hold the balance of power in that State who are in sympathy with the principles and policies of the Republican party as expressed in its conduct of the National administration, and who disapprove of the same party's policy in the State. In what position did a voter 
belonging to this number find himself in I890? A Governor and Legislature were to be chosen. If the voter wished to express himself on the local question (prohibition) he voted the Democratic ticket; but thereby he endangered to some extent the National policy of the Republicans, for the new Legislature was to choose a United States Senator and with the help of the Governor might so arrange the Congressional districts of the State as to favor the National policy which he disapproved. If he voted the Republican ticket he lost his voice in State matters, or rather expressed himself in a way he did not desire. On one or the other horn of this dilemma he was sure to be impaled! Other instances in abundance will occur to any one who has followed the course of our political history.

The intrusion of National politics into the sphere of State action often causes Senators to sit in the National Legislature who misrepresent the settled and abiding convictions of the major part of their constituency. This is brought about in two ways. First, by the minority party's securing control of the State Legislature. Cases of this kind are notorious. Connecticut, for example, has three times cast her electoral vote for the Democratic presidential nominee, but she is now and will continue to be represented (or misrepresented) by two Republican Senators. In the case of Connecticut this is brought about by a most inequitable method of choosing the Legislature; but the same result, though less likely, would be possible if all State Legislators represented districts of exact equality in the number of their inhabitants. Secondly, misrepresentation occurs when a party which is or would be a minority party on National issues, becomes a majority party in any State because State issues have temporarily obscured National issues. In off years, $i$. e., when no National election was held, Ohio has several times chosen a Democratic Legislature and consequently has had one Democratic Senator most of the time for years though she has cast her electoral vote (with the exception of a single elector's vote in I 892) for the Republican Presidential candidate since the organization of that party. Virginia, as a result of the contest over the readjustment of her debt, recently had two Senators who acted with the Republicans, though her allegiance to the National Democracy did not waver meanwhile.

The most pernicious influence of the blending of National and State politics is its powerful tendency to divert the attention of law-makers and people alike from vital State matters. The magnitude of this evil is apparent in view of the wide range of important legislation falling entirely within the field of State action. 
The laws which touch a man's daily life most frequently and most materially are State laws;-laws in reference to property, marriage, inheritance, corporations, labor, public health, and pauperism. Does he commit a crime? He is tried in a State Court. Does he pay taxes? He does so largely according to State law. Is his life safe and are his rights secure? The State makes them so. Does a mob threaten destruction and bloodshed? The State suppresses it. To defend a man against his commonest dangers the National arm is impotent. The baneful result of excessive interest in National affairs is manifest in the character and work of Legislatures whose members are chosen not so much for their fitness to legislate, as for the positions they take on National questions. On this point James Bryce remarks: "In one respect this connection is no unmixed benefit, for it has helped to make the National parties powerful and their strife intense in these lastnamed bodies (State Legislatures). Every vote in the Senate is so important to the great parties that they are forced to struggle for the ascendency in each of the State Legislatures by whom the Senators are elected." The voters are urged to cast their ballots for certain candidates for State office because a United States Senator is to be chosen, or because the State is to be redistricted, or, forsooth, for the moral effects which the result will have in determining a National contest which perchance is yet in the dim distance! Such a method results in sending inferior men to the Legislative halls. The voter of independent tendencies is restrained from administering a just rebuke to his party and defeating an unworthy aspirant for office, for fear of injuring some National policy dear to his heart. Not long ago we were treated to the spectacle of an Ex-President of the United States arguing on. the stump that tariff reformers should vote for a certain man for Governor of New York because his defeat would imperil the cause in which they were interested. The argument was, under our system, as sound in logic as it was effective in practice. But what shall we say of a system that requires a voter to sacrifice what he considers the best interests of the great State of New York to his interest in tariff reform which must come if it comes at all through the National Legislature? When the Republicans of Massachusetts met in caucuses last fall to nominate candidates for the State Legislature, the question most often asked as to a possible candidate was,-whom he favored for United States Senator. What has such a question to do with a man's fitness to legislate for his fellow citizens? In the memorable campaign between Douglas and Lincoln in 1858 the sole 
question made prominent in the canvas was whether Lincoln or Douglas should be Senator. With that question uppermost each voter decided for whom to vote for members of the State Legislature. Yet such is the perversity of the system that Douglas got the seat though Lincoln led on the popular vote! If the people of Illinois got a good Legislature it was solely by the favor of a gracious Providence.

Much is heard of late about the poor quality of our Legislatures. Perhaps their quality would improve if they were chosen more with reference to their chief function.

The protracted and bitter controversy in the New York Legislature which followed the resignation of Senators Conkling and Platt, the disgraceful scenes which preceded the election of Senator Blodgett by the New Jersey Legislature, are still fresh in memory, to say nothing of other contests full of bitterness and recrimination which have taken the time and diverted the attention of legislators for weeks or months from their legitimate business, as well as debauched their morals and ruined their reputations.

What is the remedy for these evils? The answer is plain. Let the people elect the Senators and put the duty of dividing the States into Congressional districts somewhere else than in the legislative department of the States. Various methods of accomplishing the latter object might be adopted. For one, each State might choose by popular vote a commission whose duty it should be to divide the States into congressional districts. But whatever method might be adopted it is hardly conceivable that it could produce worse gerrymandering than the present method. These things done, the theory that the spheres of the National and State governments are distinct would be completely embodied in law and we might expect the practice of our politics to become more and more conformed to it.

The United States Senate is justly deemed by thoughtful critics of our Government the flower of our Legislative bodies. Would the proposed change detract from its dignity or impair its usefulness? By no means. It is not the purpose of this paper to discuss the causes which have made the United States Senate what it is. It is sufficient to say that they are numerous and that the election of its members by the State Legislatures has contributed little or nothing to the excellence of the Senate as a lawmaking body. 